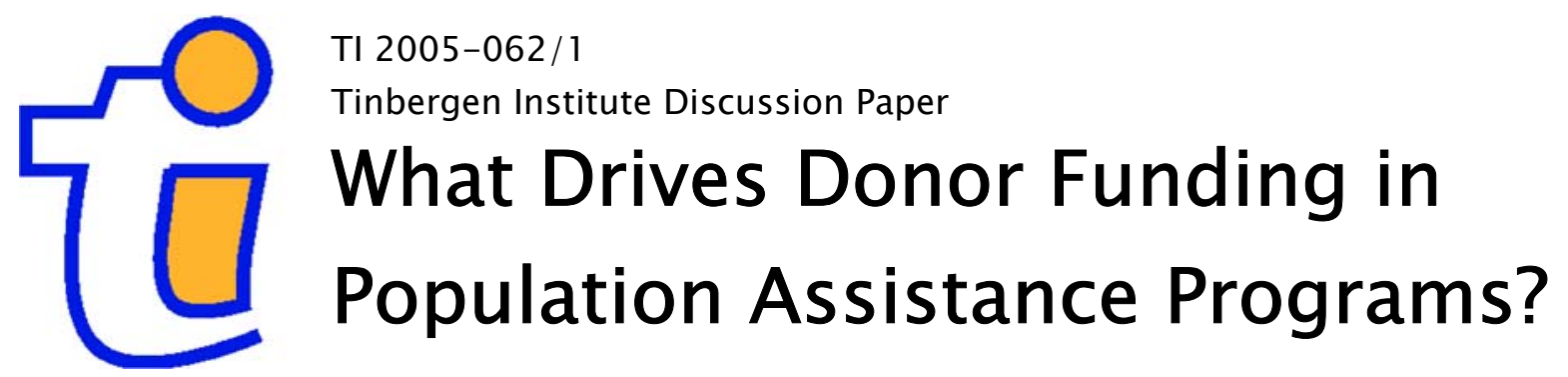

Hendrik P. van Dalen ${ }^{1,2}$

Mieke Reuser ${ }^{1}$

${ }^{1}$ NIDI, The Hague,

2 Erasmus Universiteit Rotterdam, SEOR.ECRI, and Tinbergen Institute. 


\section{Tinbergen Institute}

The Tinbergen Institute is the institute for economic research of the Erasmus Universiteit Rotterdam, Universiteit van Amsterdam, and Vrije Universiteit Amsterdam.

Tinbergen Institute Amsterdam

Roetersstraat 31

1018 WB Amsterdam

The Netherlands

Tel.: $\quad+31(0) 205513500$

Fax: $\quad+31(0) 205513555$

Tinbergen Institute Rotterdam

Burg. Oudlaan 50

3062 PA Rotterdam

The Netherlands

Tel.: $\quad+31(0) 104088900$

Fax: $\quad+31(0) 104089031$

Please send questions and/or remarks of nonscientific nature to driessen@tinbergen.nl.

Most TI discussion papers can be downloaded at http://www.tinbergen.nl. 


\title{
What Drives Donor Funding in Population Assistance Programs?*
}

\author{
Hendrik P. van Dalen ${ }^{1,2}$ and Mieke Reuser ${ }^{1}$ \\ ${ }^{1}$ Netherlands Interdisciplinary Demographic Institute (NIDI) \\ P.O. Box 11650 \\ NL - 2502 AR The Hague \\ The Netherlands \\ ${ }^{2}$ Erasmus University Rotterdam \\ Department of Economics, SEOR-ECRI and Tinbergen Institute \\ P.O. Box 1738 \\ NL-3000 DR Rotterdam \\ The Netherlands \\ Email: vandalen@few.eur.nl
}

June 15, 2005

JEL classification: D74, F35, D78, O19

Key words: Foreign aid, donors, population policy, collective action

\begin{abstract}
:
The 1994 International Conference of Population and Development (ICPD) established goals for the expansion of population assistance. This global effort has so far not sufficiently been supported by donor funds. Dynamic panel estimation methods are used to see what lies behind the sharing of burdens and level of donor contributions. Panel data on expenditures for population and AIDS activities have been collected for 21 donor countries for the years 1996-2002. Donor countries are willing to contribute to the ICPD agenda, but those contributions depend heavily on national interests and preferences and to a lesser extent on the development state of less developed countries. Political opportunism in the timing of funds is not strong. With respect to the sharing of the ICPD burden within the group of OECD/DAC countries one can say that on an aggregated scale the burden of population assistance programs is in line with the ability to pay of donor countries. Differences in funding are more connected to other factors such as the size of governments, the state of development of a country and the dominant religions in donor countries.
\end{abstract}

* The NIDI monitors resource flows for population and HIV/AIDS activities as envisioned at the ICPD Cairo Conference of 1994. The so-called Resource Flows project is a joint collaboration between UNFPA, UNAIDS and NIDI. The authors wish to stress that the views expressed in this paper are those of the authors and do not reflect the position of UNFPA or UNAIDS. 


\section{Introduction}

What determines the levels of donor government funding of population aid programs? And why do disbursements generally lag behind the good intentions? These questions are central to policy makers within government and multilateral agencies in both developing and developed world. The intentions of 179 international governments who were involved in the International Conference on Population and Development (ICPD) in the summer 1994 were quite clear and leave almost no room for what should determine funding efforts. "All countries should take steps to meet the family planning needs of their populations as soon as possible and should, in all cases by the year 2015, seek to provide universal access to a full range of safe and reliable family planning methods and to related reproductive health services which are not against the law." (par. 7.16) The donor governments promised to finance one third of the total amount of resource flows that are tied to population activities in developing countries. At that moment in time the Programme of Action was lauded with praise and entitled as "a turning point in humanity" and "a quantum leap to a higher state of energy." Today we are halfway through the 20-year Programme of Action and commentators, policy makers and advocates are wondering why donor assistance is lagging behind the growing need for resources. According to ICPD projections at that time, reproductive health costs in developing countries would likely total 17 billion US dollars in the year 2000 and 21.7 billion US dollars in 2015 (at 1993 prices). ${ }^{1}$ The unmet need in matters of family planning of developing countries and the AIDS pandemic should be the driving force behind donor behavior, but in the actual practice of foreign aid other factors - less altruistic motives impinge on population aid decisions. Up to the year 2002 the promises made have not been lived up to and this forces one to think about the question: what explains the gap between stated ambitions and actual contributions? In general one can find four types of reasons why funds are lacking behind the grand ambitions of Cairo: (1) a lack in willingness to pay; (2) a lack in ability to pay; (3) the appearance of moral hazard or 'free rider' behavior in financing global public goods; and (4) political opportunism.

The first argument is a common explanation one may come across in national press and other circles: the provision of funds is simply a matter of 'taste': a taste for caring about others, or a preference for certain programs which are in line with one's religious beliefs or Weltanschauung. For instance, one can expect some countries to be more altruistic towards the less developed world than others. Furthermore, governments of European countries are known to be more egalitarian in their national economic policies and these egalitarian 
preferences may perhaps carry over towards income differences in the world at large.

Differences in altruism should result in differences in the level of funding. But differences in taste may also be reflected in belief systems. For instance, the so-called Mexico City Policy (by its opponents called 'the Global Gag Rule') as re-imposed by president Bush in 2001 is a case in point. This rule restricts foreign non-governmental organizations (NGOs) that receive USAID family planning funds from using their own, non-USAID funds to provide abortionrelated activities. This rule was first introduced by president Reagan in 1984, but since 1993 rescinded by president Clinton. It does, of course, come as a surprise that ideology matters in making choices, what makes the US foreign aid policy different from other textbook public choices is that this policy rule can have substantial spillovers in the decisions and actions of other donor countries and recipients of aid.

The second argument - the ability to pay - will often be provided by donor governments themselves when funds are not forthcoming. Foreign aid is part of the government budget deliberations of national governments and when a government encounters a business cycle downturn or unexpected increases in government spending, ambitions have to be toned down and priorities have to change. One can expect foreign aid to be part of those changing budget priorities. Liquidity constraints or constraints on deficit financing may prevent governments from donating money. For instance, most of the European Union members have to live up to fiscal rules of the European and Monetary Union - the Stability and Growth Pact - and hence national economic developments are bound to affect foreign aid policies of those countries.

The third argument - moral hazard or contractual opportunism (Dixit, 1996, Sandler, 2004) - is the most difficult behavioral element to assess. A fundamental problem in global collective action is the problem of the free rider and this may very well be an element that distorts the generation of donor funds in the context of the Cairo conference. The question then becomes relevant whether some governments of small countries are 'free riding' on the contributions of large countries like the US and Japan? Or does the provision of development assistance produce effects which benefit only the contributors and not the 'free riders'? In other words, is the global public health good really a pure public good? The fact that developing countries should carry two thirds of the total burden suggests that the benefits of family planning and reproductive health care investment are country-specific and that the designers of the Programme of Action sensed that responsibility should be placed in the hands of those who benefit most, i.c. national governments in developing countries. 
Besides the dynamics of collective action, there may also be traces of political opportunism - the fourth explanation - in explaining donor behavior. Governments pledged to live up to the Cairo agenda but living up to this ideal involves resources, which could also be spent on internal issues offering more value for money in the eyes of the median voter. In short, is donor behavior a matter of rhetoric and opportunism or are there justifiable reasons why governments have reneged their commitments? According to an overview of population assistance from the 1970s to the 1990s by Schindlmayer $(2001,2004)$, we are led to belief that population conferences are places where money is easily raised to cash in on the attention of those gatherings, but in the years afterwards their commitment drops and donor levels drop to old levels.

The inherent difficulty with the above stated elements that affect donor funding is that each and every element is difficult to disentangle from aggregate spending figures. The difference between the ability and willingness to pay is by definition difficult to extract from revealed spending patterns and only stated preferences, e.g. revealed by targets or promises might give an idea of what governments are willing to pay. Detecting moral hazard or free riding in collective action is virtually impossible because of the intangible nature of the costs and especially the benefits of foreign aid. And last but not least, what may appear as political opportunism may well be a shift in attention that is well founded. Hence, the above stated elements that come into the process of donor decision making cannot be clearly delineated as they can in economics or political science textbooks. The main contribution of this paper is to offer an empirical examination of the driving forces and preferences behind the funds provided by donors, as envisioned in the ICPD Programme of Action. The central question what drives donor funding? - is evaluated by two dimensions: (1) the level of donor contributions; and (2) the sharing of burdens within population and AIDS programs. Before we do so, we will first explain in some detail how collective action problems exactly arise and how they may be relevant to the ICPD agenda.

\section{Theory of Collective Action}

The heart of the problem which the participants of the International Conference on Population and Development face is a problem not unlike many other foreign aid programs. Population assistance programs pose a collective action problem for the international community. Many developing nations must rely on other nations to provide them with resources and cash to finance population activities, like family planning, investments in reproductive health, AIDS programs and basic research. By increasing the welfare of a recipient country, foreign aid 
serves as a collective good, i.e. an input that produces an output that is both non-excludable and non-rival to all nations interested in the well-being of the recipient. For instance, if the US helps India and the UK is also interested in the well being of India it can free ride on the foreign aid efforts of the US. This mechanism is akin to a hos $t$ of collective action failures in foreign aid and may well explain why funding today has been lagging behind the ambitions formulated in the Programme of Action as envisioned at the International Conference on Population and Development.

The mechanism that might explain this failure is the so-called 'exploitation hypothesis', as pointed out by economists Olson and Zeckhauser (1966). They focused in their pioneering study mainly on the financing of military strategic alliances, such as the NATO. Their theor y can however be applied to other issues which share the problem of alliances in financing a public good and foreign aid is one of them. Essentially their thesis boils down to the following more formal point: if foreign aid is untied, aggregate aid to a recipient represents a fungible resource, since the source of the contribution is immaterial. The recipient's welfare depends then on the sum of aid received from others. Sub-optimality in the supply of foreign aid is then to be expected. E.g., suppose that the recipient's welfare affects the welfare of the would-be donors in a positive manner, then donor contributions will be positively related to the donor's income. Wealthier nations would have a greater desire to contribute aid and so wealthier nations will also bear a larger share of the burden than less well-off nations. In other words, some small country will exploit the benevolence of large countries. The provision of foreign aid would then be sub-optimal and some supranational action should be initiated to correct this failure. However, the manner in which foreign aid is corrected at the supranational level is crucial as policy initiatives at this level may result in no effect whatsoever if the socalled neutrality theorem applies, i.e. a redistribution of income among contributors (whose tastes may differ) has no net effect on the level of the collective good. If international UN agencies like UNAIDS or UNFPA supplement a recipient's foreign aid from revenues collected from donor nations, then foreign aid at the supranational level would simply crowd out voluntary foreign aid from donors on a dollar-for-dollar basis. It remains however an empirical question whether these conditions apply to specific foreign development aid problems.

The difficulty with the ICPD agenda is that the (reproductive) health care agenda comprises a host of different types of collective goods and each type of good calls for a different design of policy actions. Multilateral agencies, that are the recipients of unearmarked funds, are expected to be involved in the provision of global public goods that generate more 
non-excludable benefits than the goods and services supported by earmarked bilateral funds. It is believed that the latter type of funds provides certain benefits, whichflow to those who give the population assistance. The business of foreign aid may perhaps be paved with good intentions, in practice one cannot deny the role which colonial ties, favorable trade positions, governance structures, religious beliefs, geography and human rights can play in bringing about and sustaining aid flows. The presence of imperfect public goods is of crucial importance because it changes the interpretation of statistical evidence. The fact that, e.g., large countries dominate foreign assistance by means of bilateral aid may be a beneficial state of affairs as it brings about some form of centralization in foreign assistance that prevents the collective action failures that are typical in managing aid flows. Currently, the most pervasive trend in foreign aid is that recipient countries are faced with many donors who each want to receive reports and surveys about how visible or effective their policies or projects have been (Knack and Rahman, 2004). Furthermore it appears that donors poach the best 'government civil servants' in the local government to work for specific donor projects. This type of 'cherry picking' or poaching is the main reason why a fragmentation of donor efforts produces counterproductive effects.

In addition to the moralhazard problems tied to collective action in the realm of foreign aid, political opportunism is bound to appear as political actors will have different goals and in order to attain their goals they will operate strategically. This type of behavior is aptly described by public choice models in which politicians serve the needs of the median voter or who try to signal to voters by their policy actions that they are worth voting for. If this applies to the case of foreign aid then it is the interests of the voters who are served and not the interests of those living in less developed countries. The element of (enlightened) selfinterest and opportunism in providing foreign aid is well-documented (see Alesina and Dollar, 2000) and it should not come as a surprise that such elements may play a role in generating population assistance.

\section{Donor Funding Statistics}

In order to explore the question what determines size and structure of donor funding we will make use of data which UNFPA/UNAIDS/NIDI collected and reported in UNFPA's Financial Resource Flows for Population Activities Report. ${ }^{2}$ We want to examine how the various earmarked and unearmarked funds provided by 21 donor countries develop over

time. ${ }^{3}$ The earmarked funds are allocated over four categories: family planning, reproductive health care, HIV/AIDS activities and basic research (see Appendix for what these different 
population assistance categories represent). These four categories have been collected in a consistent way from 1996 onwards and hence our total sample period runs from 1996 to 2002. Examining the flow of funds over a longer stretch in time, including the years before 1996 is a more complicated exercise because of the expanded mandate of the Cairo Conference where reproductive health care was explicitly introduced (see Bulatao, 1998).

\section{Level of Disbursements}

To start with the level of funding, this is, of course, the magnitude which is at the focus of attention of the participating countries of the Cairo conference. Ambitions were stated in 1994 for the total group of OECD/DAC countries in US dollars (in 1993 prices) and in percentages. In dollars the goal for the year 2000 was set at US\$ 5.7 billion to increase over the years to the level of US\$ 7.2 billion in 2015 when the Cairo program officially ends. In percentages the primary funds should be at least 4 percent of the level of official development assistance (ODA). As one can see from Table 1 the time series patterns in the various categories and totals is quite erratic.

Table 1: Total disbursement of 21 donor countries (in million current US dollars)

\begin{tabular}{|c|c|c|c|c|c|c|c|}
\hline & \multirow[t]{2}{*}{$\begin{array}{l}\text { Unearmarked } \\
\text { contributions }\end{array}$} & \multicolumn{4}{|c|}{ Earmarked funds allocated to: } & \multirow{2}{*}{$\begin{array}{l}\text { Total primary } \\
\text { funds }\end{array}$} & \multirow[t]{2}{*}{$\begin{array}{c}\text { Primary funds } \\
\text { as } \% \text { ODA }\end{array}$} \\
\hline & & $\begin{array}{l}\text { Family } \\
\text { planning }\end{array}$ & $\begin{array}{l}\text { Reproductive } \\
\text { health }\end{array}$ & $\begin{array}{l}\text { HIV/AIDS } \\
\text { /STD }\end{array}$ & $\begin{array}{c}\text { Basic } \\
\text { Research }\end{array}$ & & \\
\hline 1996 & 648.5 & 305.0 & 241.0 & 104.7 & 56.0 & 1355.1 & 2.46 \\
\hline 1997 & 581.7 & 412.2 & 206.4 & 182.5 & 67.8 & 1450.5 & 3.00 \\
\hline 1998 & 438.0 & 454.6 & 237.6 & 237.1 & 92.1 & 1459.4 & 2.81 \\
\hline 1999 & 457.1 & 423.7 & 217.5 & 229.2 & 50.2 & 1377.7 & 2.45 \\
\hline 2000 & 537.7 & 386.0 & 237.2 & 353.0 & 55.0 & 1568.9 & 2.93 \\
\hline 2001 & 516.1 & 392.9 & 186.5 & 547.8 & 48.4 & 1691.6 & 3.24 \\
\hline 2002 & 580.6 & 396.5 & 294.7 & 769.9 & 71.6 & 2113.4 & 3.64 \\
\hline
\end{tabular}

Source: UNFPA/UNAIDS/NIDI

To start with the aggregate level: there seems to have been a clear improvement as the level of primary funds has increased from $\$ 1.4$ billion to $\$ 2.1$ billion (in current prices). And if these levels are expressed as a percentage of the aggregate level of ODA the improvement can be deemed substantial, since population assistance increased with a full percentage point: from 2.5 to 3.5 percent of ODA. However, most donor countries are lagging behind their promises if one looks at the promises once made. Figure 1 gives an impression of the gap that exists between promises and actions of donor countries as a collective entity. 
Figure 1: Gap between ambitions and actions in populationassistance, 1996-2003 (in current US dollars)*

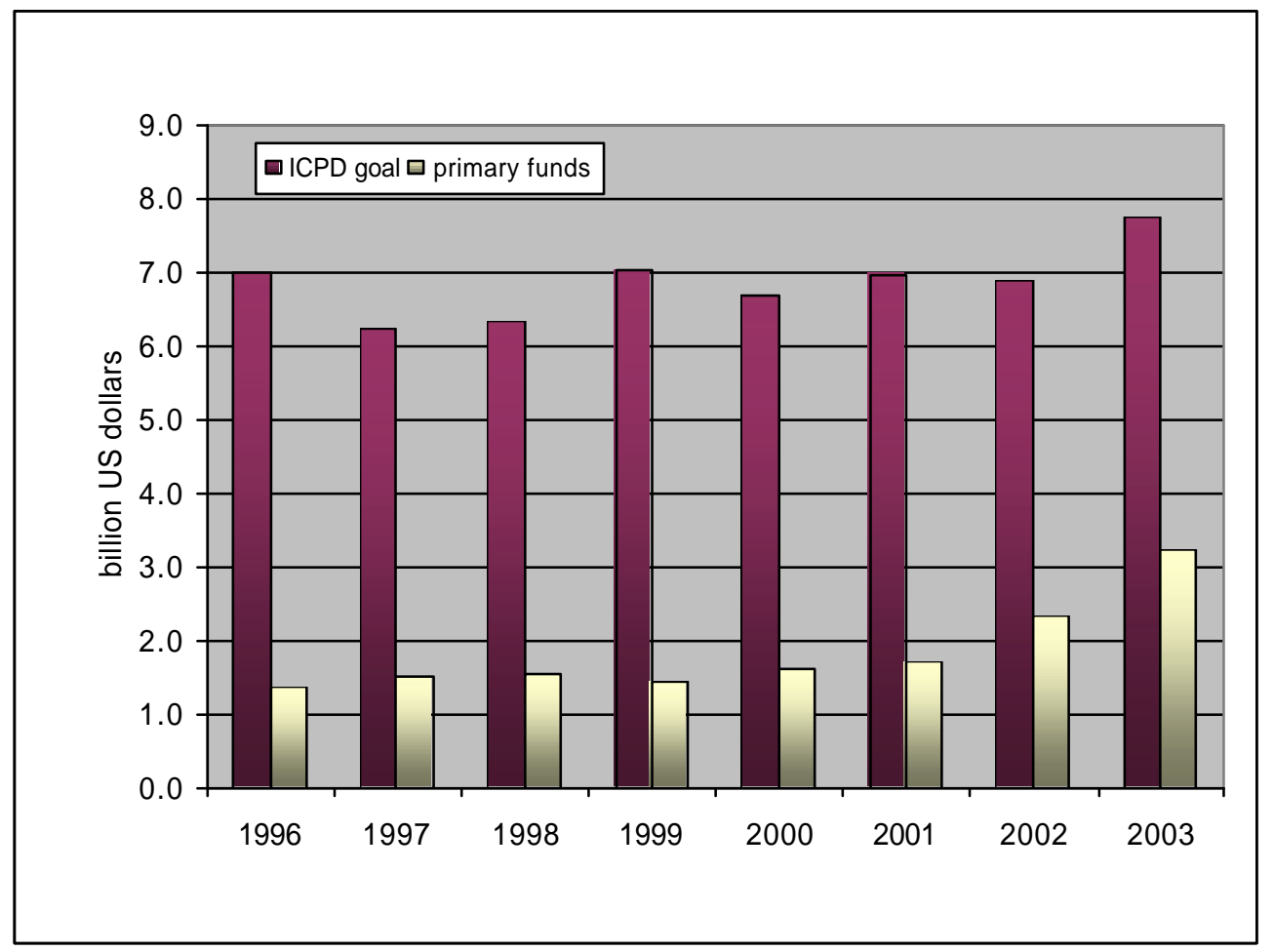

\footnotetext{
* The ICPD goal differs from the fixed numbers mentioned in the program of action and is derived from the two foreign aid goals which countries try to live up to: $0.7 \%$ of GDP to ODA and 4\% of ODA to population assistance, ergo: 0.028 percent of GDP. The year 2003 is a provisional figure and will not be included in the statistical analysis in the remainder of this paper.
}

Source: UNFPA/UNAIDS/NIDI.

The ambitions are derived from the stated goals in the de velopment programs to allocate 4 percent of ODA to population assistance and the level of official development assistance itself should ideally constitute 0.7 percent of GDP. Based on those premises the donor countries should give approximately $\$ 7$ billion (see Figure 1) annually over the period 1996-2002. But as one can see quite clearly in the figure, the actual disbursements of funds vary between $\$ 1.4$ and $\$ 2.1$ billion (see Table 1) and has been quite volatile in these seven years. The same can be said for the underlying categories. The unearmarked contributions follow a U-shape over 
time, family planning seems to follow an inverse U-pattern, HIV/AIDS spending increases with some jumps, and reproductive health and basic research are hard to describe in a simple time pattern.

\section{Sharing the ICPD Burden}

In Table 2 we present the average shares of the OECD/DAC countries in the total of funds per donor category. As one can see, each category of population assistance is characterized by a marked different distribution across donors. The unearmarked fund are however not allocated directly to a specific category as these funds are transferred to multilateral organizations and international NGOs who in turn will allocate them to the categories of the so-called 'costed package' of the ICPD agenda. To get an impression of the ability to donate funds the share in GDP per country in the total GDP of the group of 21 countries is also added to the table in column (7).

Table 2: Average shares of the burden of population activities across donor countries, $1996-2002$

\begin{tabular}{lccccccc}
\hline \multicolumn{7}{c}{ Average share over the years 1996-2002 in: } \\
\hline Country & $\begin{array}{l}\text { Unearmarked } \\
\text { contributions }\end{array}$ & $\begin{array}{c}\text { Family } \\
\text { planning }\end{array}$ & $\begin{array}{c}\text { Reproductive } \\
\text { health }\end{array}$ & $\begin{array}{c}\text { HIVIDS/ } \\
\text { STD }\end{array}$ & $\begin{array}{c}\text { Basic } \\
\text { research }\end{array}$ & $\begin{array}{c}\text { Total of } \\
\text { primary } \\
\text { funds }\end{array}$ & GDP \\
\hline Australia & $(1)$ & $(2)$ & $(3)$ & $(4)$ & $(5)$ & $(6)$ & $(7)$ \\
Austria & 0.7 & 1.1 & 3.5 & 4.2 & 6.0 & 1.9 & 1.7 \\
Belgium & 0.2 & 0.0 & 0.1 & 0.0 & 0.0 & 0.1 & 0.9 \\
Canada & 1.2 & 0.1 & 1.4 & 1.1 & 2.2 & 1.0 & 1.1 \\
Denmark & 2.5 & 1.0 & 2.7 & 4.6 & 5.2 & 2.5 & 2.8 \\
Finland & 9.5 & 0.1 & 0.7 & 0.5 & 0.2 & 3.5 & 0.7 \\
France & 3.0 & 0.2 & 1.3 & 0.4 & 0.6 & 1.4 & 0.5 \\
Germany & 2.3 & 0.0 & 0.3 & 2.6 & 3.8 & 1.3 & 6.1 \\
Ireland & 6.3 & 10.9 & 7.3 & 5.5 & 3.9 & 7.2 & 8.9 \\
Italy & 0.3 & 0.0 & 0.4 & 0.2 & 0.1 & 0.2 & 0.4 \\
Japan & 0.9 & 0.1 & 0.8 & 1.2 & 0.5 & 0.8 & 5.0 \\
Luxembourg & 17.0 & 1.1 & 7.1 & 0.9 & 1.8 & 7.3 & 18.7 \\
Netherlands & 0.2 & 0.1 & 0.2 & 0.7 & 0.0 & 0.3 & 0.1 \\
New Zealand & 15.9 & 2.4 & 10.5 & 5.1 & 6.3 & 8.8 & 1.7 \\
Norway & 0.3 & 0.0 & 0.1 & 0.1 & 0.1 & 0.1 & 0.2 \\
Portugal & 7.9 & 0.7 & 2.4 & 2.4 & 2.2 & 3.8 & 0.7 \\
Spain & 0.1 & 0.0 & 0.0 & 0.0 & 0.3 & 0.0 & 0.5 \\
Sweden & 0.1 & 0.5 & 2.0 & 0.2 & 0.1 & 0.5 & 2.6 \\
Switzerland & 6.4 & 0.2 & 7.6 & 3.1 & 3.3 & 4.1 & 1.1 \\
UK & 2.7 & 0.2 & 0.8 & 0.4 & 1.0 & 1.2 & 1.1 \\
USA & 9.0 & 3.9 & 15.9 & 6.9 & 5.0 & 7.9 & 6.0 \\
\hline Source & 13.5 & 77.2 & 34.8 & 59.7 & 57.5 & 46.1 & 39.3 \\
\hline
\end{tabular}

Source: UNFPA/UNAIDS/NIDI 
One can see clearly how the allocation differs quite distinctly across the different categories. The United States is the dominant player in questions of family planning in which it carries almost 80 percent of the total burden. To a lesser extent, but nevertheless a clear dominant position, can be traced in questions of HIV/AIDS activities and basic research where almost 60 percent of the funds comes from the United States. In case of unearmarked contributions and contributions to the reproductive health care category the smaller countries such as Norway, Denmark, Sweden and the Netherlands are relatively 'big' players. Of course, some of these country differences are confounded when the total of primary funds are evaluated visa-vis the carrying capacity of countries.

Figure 2: Average share of donor countries in primary funds and official development assistance (ODA) 1996-2002

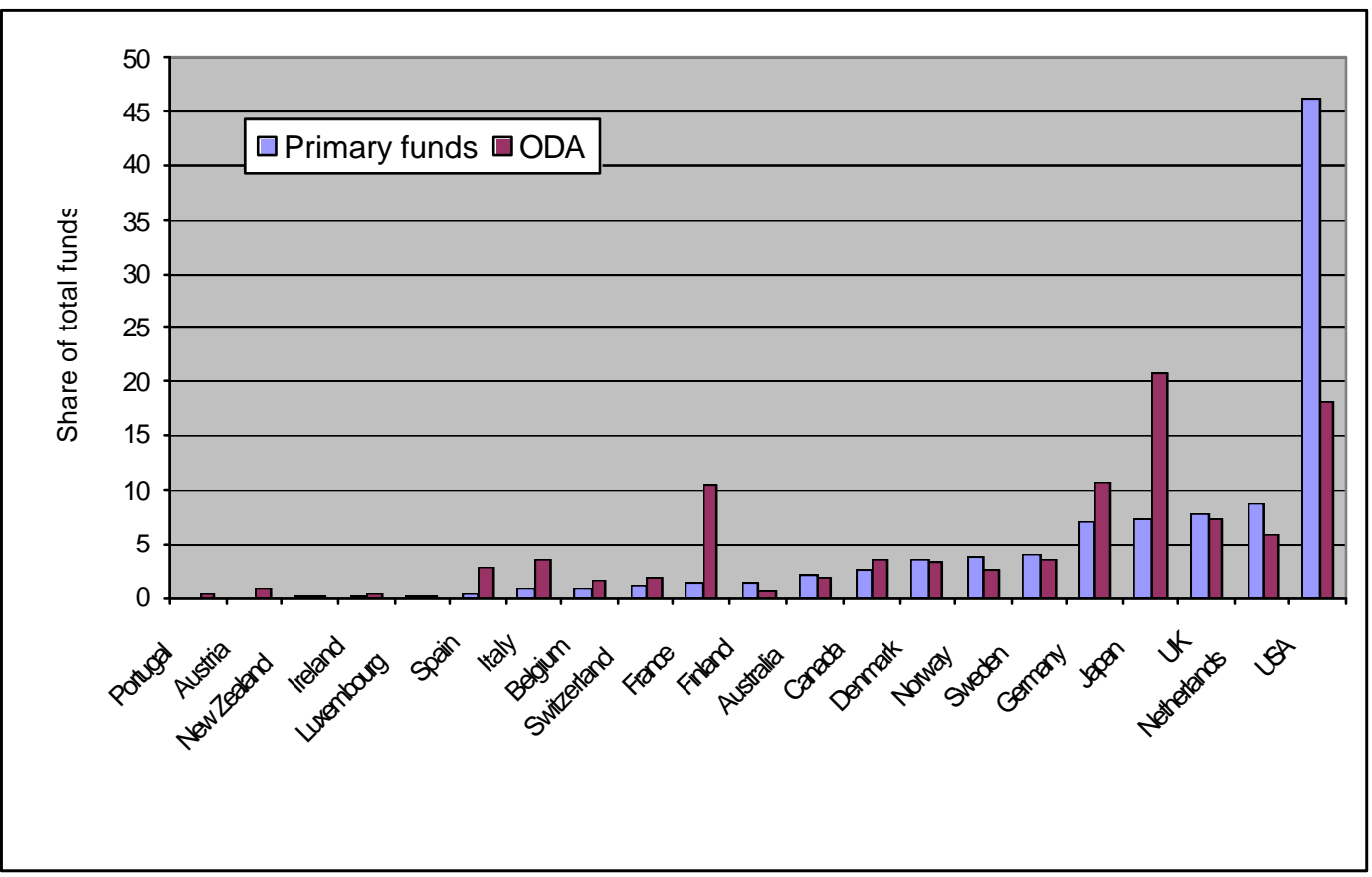

Source: UNFPA/UNAIDS/NIDI

Clear 'outperformers' in donor funding are respectively Norway (5.4 times its GDP share), the Netherlands (factor 5.2), Denmark (factor 5.0) and Sweden (factor 3.7). And, of course, there also countries that underperform compared to their level of GDP such as Austria (11 percent of its GDP share), Italy (16 percent), Spain (19 percent), France (21 percent), Japan (39 percent). These type of rankings compare well to evaluations made by Cairo-watchers such as International Planned Parenthood Federation (IPPF) and Population Action 
International (PAI). A striking fact in this ranking of outperformers and underperformers is that the same ranking does not correspond closely with that of ODA.

In Figure 2 the primary funds share (of Table 1) is compared with the ODA share of these 21 countries. Countries such as Japan, France, Germany, Spain and Italy apparently have a different preference for the allocation of ODA as their ODA share is far larger than their population aid share, and the United States has a far lower share when it comes to ODA.

\section{Figure 3: Allocation of Official Development Assistance (ODA) in OECD/DAC} countries, 2003*

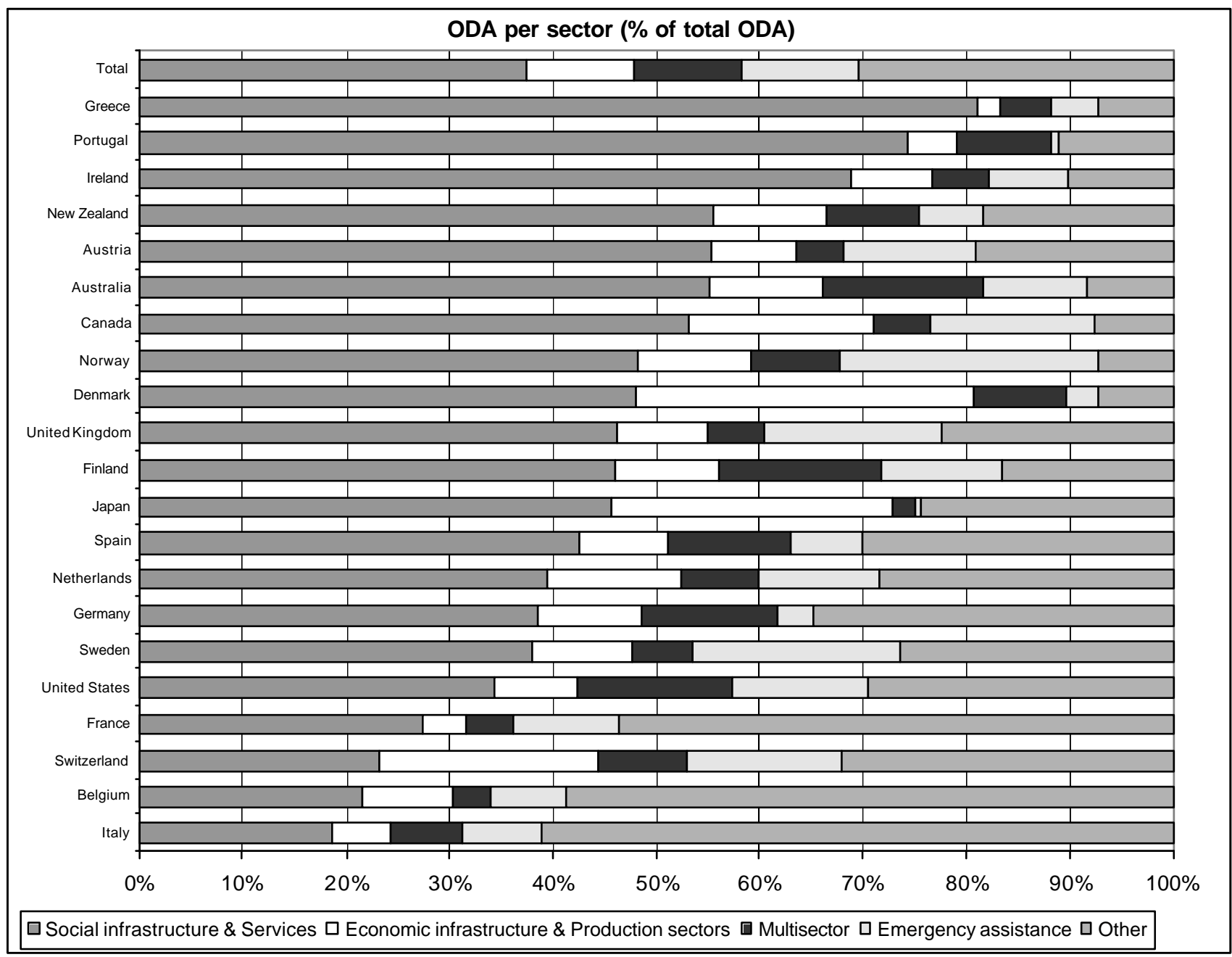

* Social infrastructure and services = education, health, population, employment, housing; economic infrastructure and production sectors = transport, energy, banking, agriculture, industry, trad e, tourism; multi sector $=$ environment protection, women in development, urban and rural development; and other $=$ commodity aid, action relating to debt, administrative costs

Source: OECD 
This suggests that countries have either different interests or differ with respect to their comparative advantages in providing population aid. Figure 3 offers a more detailed picture for all OECD/DAC countries of their allocation of development assistance funds.

To examine a number of examples of 'impure altruists' we can start with Japan. In the case of Japan it becomes clear by reading the ODA Charter where the ultimate objective of Japanese development assistance is stated as: "to contribute to the peace and development of the international community, and thereby help ensure Japan's own security and prosperity." Foreign aid can be viewed as enlightened self interest and this becomes apparent by the large share of loans (55 percent) of the bilateral aid of Japan - aid is tacitly seen as an investment in less developed countries and not a gift - and a clear priority attribution of ODA to Asia: 74 percent of ODA is disbursed to the region with China, Indonesia, India and the Phillipines as the largest recipients.

Similar interests can be traced in the French view on ODA, which is managed by a diverse number of actors, each with its specific goals. The Ministry of Foreign Affairs combines the goal of solidarity with influence in support of French diplomacy. Its Ministry of Economic Affairs, Finance and Industry aims at promoting export, investment and economic relations with developing countries. Considering the preoccupation of French development policy with such goals, it does not come as a surprise that population aid does not appeal to the French government as population assistance does not generate benefits which might help politicians win an election or generate benefits in general. The geographical bias in assistance is present in the case of France, but it is also prevalent among most Europeans. Europeans by and large think that geographic proximity should be an element in helping the poor. Japan is best placed to help Asia, the United States should help Latin America and Europeans are of the opinion that Europe is best placed to help Africa. Only the people in new EU member states have their doubts and think that the United States is best placed to help Africa (Eurobarometer, 2005). The French citizen is very outspoken with respect to helping the poor in Africa, but then again this is a continent with some firm roots in the French republic.

The enlightened self interest which drives funding in France and Japan is in stark contrast with the reviews which the Norwegian and Dutch government received in the past. Both are leading countries in terms of donor contributions to the ICPD Programme of Action and development assistance in general. Official development assistance totaled 0.9 and 0.8 percent, respectively, of their gross national product. These governments are firmly devoted to fighting poverty in LDCs. It is known from numerous policy documents that the Norwegian government emphasizes a rights-based approach to development in connection with the fight 
against poverty. In other words, it will assist partner countries to incorporate obligations to deliver human rights within their national poverty reduction strategies. The Millenium Development Goals are at the central reference point for Norwegian aid policy. The same can be said of the Dutch government, where poverty reduction is the overarching rationale for its development assistance. What strikes us is that almost 80 percent of the Dutch citizens believe that development aid provided by their government makes a difference for people living in developing countries. This is in marked contrast with, e.g. the aid provided by French and Italian governments: approximately 50 percent of the citizens of these countries believe nationally provided development aid makes a difference (Eurobarometer, 2005). The Dutch also favor the use of country-owned strategies and it tries to make extensive use of private and non-governmental organizations in implementing its programs. This policy stance is in line with the goals and intentions stated in the ICPD agenda. E.g., family planning and reproductive health care are typically about empowering women and giving households the opportunity to make well-balanced family choices.

Finally, we cannot neglect the influence of the United States in supporting population assistance and the ICPD agenda. The role of the United States has always been large in matters of population assistance (see Schindlmayer, 2004) and recently the clear shift towards fighting HIV/AIDS has become a dominant theme in the allocation of primary funds by the United States (see Van Dalen and Reuser, 2005) thanks to such initiatives as the President's Emergency Plan for AIDS Relief (PEPFAR). The initiative may be well chosen as alarming reports such as those by Jha et al. (2002) make clear that that the annual costs of fighting HIV/AIDS will rise from $\$ 15$ billion in 2007 to $\$ 25$ billion in 2015. However, the role of the United States cannot be well understood if attention is focused on aggregate US figures. The leading role in matters of population assistance have given the US government power to affect behavior of other donors and international non-governmental organizations. The Mexico City Policy, instituted by the US president Bush, is a telling example of how political ideology can affect donor funding behavior. As mentioned earlier, this policy restricts foreign NGOs that receive USAID family planning funds from using their own, non-USAID funds to provide abortion related activities. What complicates the case of the ICPD agenda is that this policy rule could affect foreign NGO funding in a direct manner, it prevents freedom of $\operatorname{speech}^{4}$ and in the long-run it could undermine international cooperation as the United States as a dominant player can set the rules which may not always coincide with preferences of other donors. 5 
Of course, each country tells a different story, and what these examples illustrate is that diverse interests, ideologies, income development and historical backgrounds play a role in generating population assistance. The main aim of this paper is to shed light on which factors come into play in supporting the Programme of Action of the ICPD agenda.

\section{Method and Results}

To explain the behavior of donors in funding over time we have pooled the experiences of the 21 countries and employed the method of dynamic panel estimation. ${ }^{6}$ Despite a small time interval (1996-2002) we still have substantial variation across the various countries to distill a clear pattern of funding. Needless to say, this model will be more useful in describing the patterns across countries than within countries across time because of the short sample period. We will focus on examining the driving forces behind the level of funding for each of the ICPD categories of reproductive health.

\section{Explanatory Variables}

Among the most important potential explanatory factors are income and income distribution of a country, the pro-foreign assistance stance of some countries as measured by the share of official development assistance as a percentage of GDP, the human development index in the donor countries and in the Least Developed Countries (LDC), the business cycle state of an economy as measured by the level of unemployment, and the influence of particular religions in a country. The explanatory variables come from different sources. The level of GDP (total and per capita), Official Development Assistance (excluding population assistance, expressed as a percentage of GDP), government size (as measured by general government final consumption expenditure as percentage of GDP), unemployment rate (as percentage of labor force) are all extracted from the World Bank Development Indicators (edition 2004). The ODA variable is corrected for the influence of population aid by subtracting the level of primary funds from the level of ODA. The Human Development Index is a weighted average of income, literacy and life expectancy, with weights as described in Human Development Reports of the UN, but with data from the World Development Indicators. The income inequality measures (i.c. Gini indices) come from the Luxembourg Income Study which reports at irregular intervals the state of income inequality in a host of OECD countries. All the previously stated variables are defined in logarithmic form so the relevant coefficients can be more easily interpreted as elasticities. The religion dummies apply to the presence of (Roman) Catholic, Lutheran or Protestant religion belonging to the two most dominant 
religions in each country as registered by UNESCO (2000). ${ }^{7}$ Finally, we have included membership of the European Union as an explanatory dummy because we expect that some countries will take account of the fact that the European Union is a separate contributor to the ICPD agenda and changes in donor funding from the EU can have some effect on funding behavior of individual EU members.

To test the idea of opportunism in funding, we will use the case of the population conference held in The Hague in February 1999 as our testing ground. An opportunist government would raise its level of funding in the year 1999 when the focus of the developed world is on the developing world and decrease its funding afterwards. For this purpose we defined a dummy variable that takes on the value zero before 1999, has the value 1 in the year 1999 and for the remaining three years in our sample period the dummy value is -1 . The assumption is therefore that during the year in which a population conference is held governments raise their contributions and in the subsequent three years they decrease their contributions. The end result of this strategic behavior is that by shifting resources in time they 'buy' attention. The developing countries will, however, be on the losing side because it simply means that donors diminish their contributions in net terms.

\section{Explaining the Level of Disbursements}

The level of primary funds and the various subcategories by country $i$ (where $\mathrm{i}=1,2, \ldots 21$ OECD/DAC members) at time $t$ are explained by a vector of variables, as described above. Both the level of primary funds, split up by spending categories, and GDP are measured in constant US dollars (in 1995 prices). All the explanatory variables have been summed up above. Special attention should be paid to the variable, which approximates the altruistic concern of donor countries for the welfare of recipients: the level of human development in the Less Developed Countries as approximated by the HDI. The latter variable is added to test for an altruistic concern for those living in the developing countries and to see whether a closing of the gap (in terms of HDI) between developing and donor countries leads to less primary funds or not. The results of the estimation exercise are presented in Table 3.

One robust observation, which can be derived from this table, is the tight relationship between national income development and the generation of primary funds. The total income elasticity is 1.0 and for the underlying contribution categories it varies between 1.0 and 1.3. Essentially, this boils down to the message that "what's good for the developed world, is good for the developing world". In general one can say that a 10 percent in crease in real GDP leads to a 10 percent increase in real primary funds. 
Table 3: Explaining the Level of Disbursements (in constant 1995 US dollars), 1996-2002

\begin{tabular}{|c|c|c|c|c|c|c|}
\hline & Unearmarked & & Earmarked cont & ibutions goin & to: & Total primary \\
\hline $\begin{array}{l}\text { Explanatory } \\
\text { variables: }\end{array}$ & & $\begin{array}{l}\text { Family } \\
\text { planning }\end{array}$ & $\begin{array}{l}\text { Reproductive } \\
\text { health }\end{array}$ & HIV/AIDS & Basic research & $\begin{array}{c}\text { Sum of (1) to } \\
\text { (5) }\end{array}$ \\
\hline & (1) & (2) & (3) & (4) & (5) & (6) \\
\hline GDP & $1.01 * *$ & $0.88 * *$ & $1.23 * *$ & $0.96 * *$ & $1.14 * *$ & $0.99 * *$ \\
\hline & (13.40) & (5.00) & (17.86) & (10.33) & (5.53) & (11.88) \\
\hline Unemployment & $-0.40^{*}$ & -0.24 & -0.14 & 0.45 & -0.35 & -0.27 \\
\hline & (2.03) & $(0.81)$ & $(0.62)$ & (1.74) & $(0.82)$ & (1.56) \\
\hline EU member & $-0.37 *$ & $-0.88 * *$ & 0.31 & 0.14 & -0.40 & -0.14 \\
\hline & (2.01) & (2.79) & $(1.31)$ & $(0.59)$ & $(0.97)$ & $(0.83)$ \\
\hline The Hague Forum & $0.07 *$ & $0.22 * *$ & $0.22 * *$ & $0.17 *$ & 0.15 & 0.04 \\
\hline & (2.01) & (2.69) & $(4.07)$ & (2.38) & (1.44) & (1.08) \\
\hline HDI donor & $17.92 *$ & -0.75 & 18.19 & $46.58 * *$ & -8.81 & $17.73^{* *}$ \\
\hline & (2.27) & $(0.05)$ & $(1.78)$ & $(4.96)$ & $(0.43)$ & $(2.78)$ \\
\hline HDI LDC & $-3.47 *$ & -5.92 & -2.52 & 0.24 & $-11.42 * *$ & -1.76 \\
\hline & (2.46) & (1.92) & $(1.31)$ & $(0.12)$ & (3.55) & (1.08) \\
\hline ODA/GDP & $0.38 * *$ & -0.33 & $0.37 *$ & $1.06^{* *}$ & 0.56 & $0.32 *$ \\
\hline & (2.60) & (1.04) & $(2.35)$ & (4.71) & (1.26) & (2.14) \\
\hline Government size & $2.68 * *$ & $-2.47 *$ & 1.06 & $2.97 * *$ & 1.54 & $1.27^{*}$ \\
\hline & (3.60) & (2.00) & (1.38) & (3.26) & $(0.90)$ & (2.26) \\
\hline Income inequality & -0.97 & $-10.65^{* *}$ & 0.23 & 1.75 & -2.93 & -0.17 \\
\hline & $(0.92)$ & $(6.06)$ & $(0.16)$ & (1.67) & (1.33) & $(0.18)$ \\
\hline Catholic & $-1.34 * *$ & $-2.95 * *$ & -0.57 & -0.34 & $1.22 *$ & $-0.85^{* *}$ \\
\hline & (5.55) & $(5.38)$ & (1.55) & $(1.20)$ & (2.37) & $(3.82)$ \\
\hline Lutheran & $2.23 * *$ & -0.61 & $3.23 * *$ & $1.91 * *$ & 1.05 & $2.45^{* *}$ \\
\hline & $(4.26)$ & $(0.64)$ & (5.41) & $(3.42)$ & (1.26) & (6.69) \\
\hline Protestant & $1.59 * *$ & $3.52 * *$ & $3.03 * *$ & $2.65^{* *}$ & 0.25 & $1.76^{* *}$ \\
\hline & (3.56) & $(9.35)$ & $(7.86)$ & $(6.98)$ & $(0.44)$ & (11.41) \\
\hline Constant & $-12.09^{*}$ & $25.34 *$ & $-20.36^{*}$ & -11.50 & -15.68 & $-16.32 *$ \\
\hline & (2.38) & (2.36) & (2.90) & $(1.61)$ & (1.33) & $(3.05)$ \\
\hline $\mathrm{N}=$ & 135 & 109 & 133 & 123 & 103 & 140 \\
\hline Pseudo $\mathrm{R}^{2}$ & 0.82 & 0.57 & 0.56 & 0.57 & 0.40 & 0.85 \\
\hline Loglikelihood $\mathrm{L}_{\mathrm{A}}$ & -51.8 & -114.9 & -129.0 & -119.9 & -142.6 & -43.7 \\
\hline Loglikelihood Lo & -284.8 & -268.3 & -293.8 & -281.4 & -236.2 & -292.4 \\
\hline
\end{tabular}

* Significance at $5 \%$ level, $* *$ significance at $1 \%$ level. Absolute t-statistics are in brackets below the coefficients. In using Generalized Least Squares panel specific AR(1) processes were added to correct for autocorrelation in the time series, and estimates are also corrected for heteroskedasticity. To gauge the goodness of fit we present two $\log$ likelihood values: $\mathrm{L}_{\mathrm{A}}$ for the full model and $\mathrm{L}_{0}$ for the model without any explanatory variables or correction for serial correlation or heteroskedasticity. 
The effect of unemployment is hardly traceable in the level of donor disbursements. The sign of parameters are in accordance with what one would expect: in hard times - when the level of unemployment increases - the level of primary funds decreases and the reverse applies to states of the economy where unemployment drops. The dummy variable expressing membership of the European Union does not affect on the aggregate level of funding. Only in the case of family planning can one trace some signs of substitution. The European Union spent, for example, in 200222 percent of its total primary funds on family planning projects whereas most EU members have percentages which fall far below this allocation percentage (only Germany exceeds the EU level with 38 percent spent on family planning).

Traces of political opportunism are hard to detect. The so-called 'The Hague Forum' offers a possibility to test for the existence of political opportunism. Schindlmayer (2001) makes the claim that such opportunism is widespread in the years surrounding major population policy conferences. The results in Table 3 do not give an unambiguous verdict about the presence of political opportunism in offering population aid. We tested a number of dummy variables capturing the manner in opportunism could apply to funding behavior by varying the length of years in which funds are decreased after increasing in the year in which the population conference was held, when attention for the cause of the ICPD agenda is highest. For the discussion we will only focus on the robust outcomes and a robust finding is that at the aggregate level of primary funds there is no trace of opportunism to be found. There is, however, some opportunism present in the funding of family planning and reproductive health. Considering the absence of an effect at the aggregate level, this type of opportunism could well be a consequence of shifting priorities decided at The Hague Forum.

The most interesting results are to be found in parameter estimates appr oximating the altruistic profile of donor countries. To start with the concern with the fate of LDCs, the estimation results show that for most health spending categories the level of development, as approximated by HDI of LDCs as a group, is of no concern. It is, however, an issue in the case of unearmarked funds and basic research. Both effects are understandable since the benefits of basic research generally fall on the recipient countries and when the level of development improves it stands to reason that recipients should carry more responsibility in funding this relatively small part of the so-called 'costed package'. The fact that unearmarked contributions are sensitive to development is in large part an effect that can be ascribed to the many small (European) countries that contribute to multilateral organizations and that are willing to support the developing countries more when things go bad, but who will decrease some of its funding when developing countries close the development gap. One should, 
however, consider this effect in conjunction with the HDI of the donor countries. For the unearmarked contributions and HIV/AIDS one can see large elasticities: if the HDI of a country increases with one percent, the unearmarked contributions increase with 18 percent. Of course, increases in HDI on the donor side are not very likely to show large or sudden fluctuations over time. From 1996 to 2002 the average HDI for all OECD/DAC combined increased from 92.3 to 93.8 . To be certain about the altruistic feelings for developing countries we tested whether the HDI of more specific regions are relevant in explaining donor funding. In most cases the results do not change. There is, however, one exception, viz. that donor countries are particularly sensitive to human development in Sub-Saharan Africa when it comes to donating funds for HIV/AIDS. This stands to reason since this particular region has the highest HIV/AIDS prevalence in the world.

An alternative proxy for altruistic feelings of donor governments is reflected in the level of official development assistance (as a percentage of GDP), the size of the government, and the level of income inequality in a donor country. The latter variable does not provide much explanatory power. Only in the case of the family planning can one detect a clear force that is in line with theoretical expectations: the more unequal the income distribution is in the donor country, the less such a country will give for aid projects, i.c. family planning. The government size is perhaps an imperfect proxy as a driving force for development aid, but it is nevertheless stressed by Addison et al. (2004) that a member's ability to bear financial responsibility for development aid commitments depends on the size of the public sector in that country. The relationship is straightforward: the capacity to fund development aid programs depends very much on the government's ability to tax and the more a government can tax the easier it can finance aid programs. In Table 3 there is some evidence of the positive relationship between government size and population aid levels, but it is not robust across the different categories. The relationship is most clearly illustrated for the case of unearmarked contributions and HIV/AIDS projects. The unearmarked case is understandable as the funds which go the UN-organizations are dominated by Northern European countries, which are known for having a large government size. These governments are also known for contributing a relatively large amount of money to ODA in general. The respective ODAcoefficients per contribution category give a clear idea how additional foreign aid resources are allocated. Increases in foreign aid resources are allocated to HIV/AIDS to be followed by unearmarked contributions. The absence of a relation with family planning spending is quite striking as this used to be the focus of attention at many population conferences in the past. A 
plausible reason why this is so may be that these organizations have goals or an ideology that may diverge from the policy stance of Catholic donors.

And this brings us to the last variable of interest: religion. As is known from research on private donations to churches and other charity goals (e.g. Regnerus et al. 1998, Iannaccone, 1998), differences between religions play a large role in the level of donations. Religion itself is a clear force in explaining the level of funds across countries. As one can see countries where the Catholicism belongs to one of the top two religions in a country exerts a clear negative force with respect to donations to multilateral organizations (as approximated by unearmarked funding in column 1) and family planning projects. If the Protestant or Lutheran religion belongs to one the dominant religions in the donor country this negative effect is counterbalanced or even overcompensated. However, we should be careful in putting too much weight on the religious factor and not confuse this element with a country characteristic. It may well be the case that a binding factor in giving development aid plays a dominant role that coincides with the religious dummy variables. It is well-known that the Scandinavian countries fund a relatively high share of ODA or population assistance and these countries happen to be dominated by the Lutheran religion.

\section{Are Burdens Shared Equally?}

The previous model tried to mimic the behavior of a typical donor government. However, the question that concerns collective action in case of a public good is the question of sharing of burdens. In case the global public good has all the characteristics of a pure public good it is crucial to know whether anyone or any nation free rides on the efforts of others. If the public good is impure - as it is in most cases - and yields certain private benefits the verdict of free riding is more difficult to make as the different private benefits can be just the reason why donor countries differ in their contributions.

The standard measure to reflect on the burden-sharing capacity of a donor country is the share of GDP whichis devoted to financing population activities as envisioned in the Programme of Action. Olsen and Zeckhauser (1966) were the first to check whether there exist in the practice of the NATO some form of 'exploitation' by the small countries of the large countries within a defense alliance. This possibility is traditionally tested nonparametrically by checking the (Spearman rank) correlation between the burden ranks and their GDP ranks. ${ }^{8}$ If a significant positive correlation exists, then this could suggest that the rich members of an alliance carry a disproportionately large burden of the project, and in our 
case the ICPD agenda. The alternative $\left(\mathrm{H}_{1}\right)$ and null hypothesis $\left(\mathrm{H}_{0}\right)$ for rank correlation test are:

$\mathrm{H}_{1}$ : Within the club of donors of the ICPD, there is a positive association between the donors' GDP and their share of GDP devoted to funding the 'costed population package'.

$\mathrm{H}_{0}$ : There is no association between these variables.

This simple test is performed in Table 4, where the Spearman test is shown per year and for the full sample period. The first conclusion to be derived from Table 4 is that the exploitation hypothesis does not apply to the case of population assistance.

Table 4: Spearman Rank Correlations Between Donor Funds (as percentage of GDP) and GDP of Donor Countries*

\begin{tabular}{|c|c|c|c|c|c|c|c|}
\hline & $\begin{array}{l}\text { Unearmarked } \\
\text { contributions }\end{array}$ & & Earmarked func & Is allocated to & & $\begin{array}{l}\text { Total primary } \\
\text { funds }\end{array}$ & ODA \\
\hline & & $\begin{array}{l}\text { Family } \\
\text { planning }\end{array}$ & $\begin{array}{l}\text { Reproductive } \\
\text { health }\end{array}$ & $\begin{array}{l}\text { HIV/AIDS } \\
\text { /STD }\end{array}$ & $\begin{array}{c}\text { Basic } \\
\text { Research }\end{array}$ & & \\
\hline & & & & Spearman's $\rho$ & & & \\
\hline 1996 & -0.09 & 0.18 & 0.05 & 0.15 & 0.38 & -0.04 & -0.23 \\
\hline & [0.69] & {$[0.44]$} & {$[0.83]$} & {$[0.50]$} & {$[0.08]$} & {$[0.88]$} & [0.31] \\
\hline 1997 & -0.19 & 0.19 & -0.19 & 0.22 & 0.13 & -0.03 & -0.29 \\
\hline & {$[0.41]$} & {$[0.42]$} & {$[0.43]$} & {$[0.36]$} & {$[0.58]$} & [0.89] & {$[0.19]$} \\
\hline 1998 & -0.52 & 0.18 & -0.13 & -0.17 & 0.26 & -0.16 & -0.19 \\
\hline & {$[0.02]$} & {$[0.44]$} & [0.59] & {$[0.48]$} & [0.27] & {$[0.50]$} & [0.39] \\
\hline 1999 & -0.34 & 0.09 & -0.07 & -0.26 & 0.10 & -0.19 & -0.28 \\
\hline & {$[0.14]$} & {$[0.72]$} & {$[0.78]$} & {$[0.28]$} & {$[0.68]$} & {$[0.41]$} & {$[0.22]$} \\
\hline 2000 & -0.29 & -0.07 & -0.01 & -0.01 & 0.13 & -0.22 & -0.26 \\
\hline & {$[0.20]$} & {$[0.76]$} & {$[0.96]$} & [0.95] & {$[0.56]$} & {$[0.34]$} & {$[0.26]$} \\
\hline 2001 & -0.30 & 0.03 & -0.22 & -0.12 & -0.13 & -0.29 & -0.34 \\
\hline & [0.19] & [0.91] & [0.33] & [0.59] & [0.59] & {$[0.21]$} & {$[0.13]$} \\
\hline 2002 & -0.45 & 0.27 & -0.03 & -0.07 & 0.14 & -0.27 & -0.39 \\
\hline & {$[0.04]$} & {$[0.24]$} & [0.89] & {$[0.76]$} & {$[0.55]$} & {$[0.23]$} & [0.09] \\
\hline Overall & -0.31 & 0.14 & -0.07 & -0.02 & 0.14 & -0.20 & -0.28 \\
\hline & {$[0.01]$} & {$[0.10]$} & [0.39] & [0.77] & {$[0.09]$} & {$[0.02]$} & {$[0.00]$} \\
\hline
\end{tabular}

* The coefficients denote Spearman's $\rho$ and the number in square brackets are probability values, indicating the probability of a type I error when testing the null hypothesis of no association between donor funds (as percentage of GDP) and level of GDP versus the alternative hypothesis of a positive association. 
Only for the full sample period in the case of family planning and basic research can one find traces of the exploitation of the large by the small countries. The second conclusion is that the case of 'reverse exploitation' - the exploitation of the small countries by the large countries is a more apt description in the case of unearmarked contributions, primary funds in general and Official Development Assistance.

However, the Olson and Zeckhauser test is restricted to within -ally burden sharing (measured as the contribution to collective action in relation to the contributor's ability to pay). As pointed out by Sandler and Hartley (2001) it would be more appropriate to test to the idea of burden sharing by using an among -ally indicator. Such a measure would boil down to the contributor's share of the total contribution by all members, as shown in Table 2.The following null and alternative hypotheses are relevant:

$\mathrm{H}_{1}$ : The distribution of ICPD burdens and income shares for the donors of the ICPD Programme of Action are different.

$\mathrm{H}_{0}$ : The distribution of ICPD burdens and income shares for the donors of the ICPD Programme of Action are the same.

To the test the burden sharing hypothesis we follow the approach of Addison et al. (2004) who examined burden sharing in the case of multilateral foreign aid and found some traces of 'reverse exploitation': the small countries support multilateral agencies disproportionately. The following equation is estimated by means of dynamic panel estimation:

$$
\log \frac{D_{i t}}{\sum D_{i t}}=\alpha \log \frac{G D P_{i t}}{\sum G D P_{i t}}+\sum_{j} \gamma_{i j} \log X_{i j t}+\varepsilon_{i t}
$$

The share of funds $D_{\text {it }}$ in the total of funds is explained its ability to pay, as approximated by most burden-sharing studies as the share of GDP in the group of OECD/DAC countries. If each and every country carries the burden of financing a pure public good in line with its ability to pay, the coefficient $\alpha$ would be equal to one and if we assume that everyone has the same capabilities and preferences the effect of other variables would be negligible. The 'exploitation hypothesis' would be a case of $\alpha>1$, and 'reverse exploitation' would, of course, boil down to the case of $\alpha<1$. The 'exploitation' interpretation would be applicable if the public good, i.c. reproductive health care, would be a pure global public good. As 
mentioned before, the assumption of a global public good would be valid if there are no individual-specific side benefits to the provision of foreign aid. In that respect, the term 'exploitation' is something of a misnomer because it does not necessarily signify exploitation of the big by the small countries. It could very well be the case that governments act in accordance with the principle of comparative advantages or economies of scale or they derive benefits from 'giving' based on ideological preferences or religious principles. The ability to pay is the starting point for the estimation exercise, but given the fact that is difficult to really pin down the case of exploitation the focus in this section will be on shedding light on revealed burden sharing in terms of the ability to pay as well as other factors (summed up by $j$ variables $\left.X_{\mathrm{ijt}}\right)$.

Table 5 presents the results which unambiguously show that family planning, reproductive health, HIV/AIDS and basic research are programs for which large countries pay disproportionately. The picture is reversed for unearmarked contributions. For this type of funds the small countries pay disproportionately more than their size would predict. The latter is in line with the finding of Addison et al. (2004) who review the exploitation hypothesis for multilateral aid agencies and they signs of 'reverse exploitation', where donor governments of small economies carry a disproportionately large share of the funding burdens of, e.g., UN agencies.

For the sharing of the burden of the ICPD agenda in general (see column 6), one can see that on an aggregate scale the parameter of interest $\alpha$ is virtually one. This finding is of some significance as it brings across that message that differences in funding are not so much the result of ability to pay, as approximated by the share of GDP within the group of OECD/DAC members, but far more the result of different preferences and different developments in income per capita and government size (see again column 6).

There are, of course, some sound reasons for this form of specialization across aid categories - small countries support multilateral aid organizations more than bilateral aid projects and the situation is completely the reverse for large countries - to come about since there can be substantial economies of scale in making aid work. Using multilateral organizations as the main channel of aid for small countries makes sense. Organizations like UNAIDS and UNFPA are the main multilateral organizations which are supported by unearmarked contributions and it is well-known that small countries are stable and relatively large contributors of these organizations. The share in the unearmarked contributions is positively associated with a large government and high ODA-share, both elements are marks of small (Western European) countries who dominate the pool of multilateral aid flows. 
Table 5: Explaining the sharing of financial burdens across population activities, 19962002

\begin{tabular}{|c|c|c|c|c|c|c|}
\hline \multirow{2}{*}{$\begin{array}{l} \\
\text { Explanatory } \\
\text { variables: }\end{array}$} & \multirow{2}{*}{$\begin{array}{l}\text { Unearmarked } \\
\text { contributions }\end{array}$} & \multicolumn{4}{|c|}{ Earmarked contributions going to: } & \multirow{2}{*}{$\begin{array}{c}\text { Total primary } \\
\text { funds }\end{array}$} \\
\hline & & $\begin{array}{l}\text { Family } \\
\text { planning }\end{array}$ & $\begin{array}{l}\text { Reproductive } \\
\text { health }\end{array}$ & HIV/AIDS & Basic research & \\
\hline & (1) & $(2)$ & $(3)$ & (4) & (5) & $(6)$ \\
\hline \multirow[t]{2}{*}{ Share GDP } & $0.94 * *$ & $1.09 * *$ & $1.23 * *$ & $1.21 * *$ & $1.35^{* *}$ & $0.98 * *$ \\
\hline & $(10.76)$ & $(8.21)$ & (14.12) & $(9.74)$ & $(9.14)$ & $(28.32)$ \\
\hline \multirow[t]{2}{*}{ GDP per capita } & $1.25 * *$ & -0.59 & -0.78 & $1.07 *$ & $-1.84 * *$ & $0.95 * *$ \\
\hline & $(2.96)$ & $(1.10)$ & $(1.45)$ & $(2.09)$ & $(2.85)$ & $(3.33)$ \\
\hline \multirow[t]{2}{*}{ Unemployment } & $-0.40 *$ & $-0.79 * *$ & $-0.81 * *$ & $0.71 * *$ & -0.40 & -0.27 \\
\hline & $(2.30)$ & $(2.54)$ & $(2.68)$ & $(2.60)$ & $(1.08)$ & $(1.65)$ \\
\hline \multirow[t]{2}{*}{ EU member } & $-0.60 * *$ & $-0.94 * *$ & 0.16 & $-0.67 * *$ & -0.28 & $-0.33 *$ \\
\hline & $(3.75)$ & $(3.40)$ & $(0.82)$ & $(2.68)$ & (1.13) & $(2.10)$ \\
\hline \multirow[t]{2}{*}{ ODA/GDP } & $0.43 * *$ & $-0.84 * *$ & 0.39 & $1.22 * *$ & $0.75^{*}$ & 0.24 \\
\hline & $(2.84)$ & $(2.83)$ & (1.94) & (4.63) & (2.17) & $(1.61)$ \\
\hline \multirow[t]{2}{*}{ Government size } & $3.00 * *$ & $-2.36^{*}$ & -0.67 & 1.74 & 0.38 & $1.77 * *$ \\
\hline & $(4.05)$ & $(2.07)$ & $(0.66)$ & (1.59) & $(0.26)$ & (3.08) \\
\hline \multirow[t]{2}{*}{ Income inequality } & 0.29 & $-12.04 * *$ & -2.68 & -0.43 & -3.03 & -0.02 \\
\hline & $(0.22)$ & (7.08) & $(1.52)$ & $(0.28)$ & $(1.95)$ & $(0.03)$ \\
\hline \multirow[t]{2}{*}{ Catholic } & $-1.16^{* *}$ & $-2.52 * *$ & -0.45 & 0.07 & $1.06^{* *}$ & $-0.74 * *$ \\
\hline & $(4.51)$ & (4.18) & (1.04) & $(0.20)$ & $(2.76)$ & $(3.47)$ \\
\hline \multirow[t]{2}{*}{ Lutheran } & $1.79 * *$ & 0.21 & $3.48 * *$ & $2.37 * *$ & $1.54^{*}$ & $2.38 * *$ \\
\hline & $(3.70)$ & $(0.21)$ & $(4.30)$ & $(4.73)$ & (2.14) & $(7.38)$ \\
\hline \multirow[t]{2}{*}{ Protestant } & $1.56^{* *}$ & $3.48 * *$ & $3.25 * *$ & $2.74 * *$ & 0.02 & $1.79 * *$ \\
\hline & $(5.18)$ & (10.19) & $(6.77)$ & $(8.38)$ & $(0.06)$ & (11.21) \\
\hline \multirow[t]{2}{*}{ Constant } & -16.90 & $43.12^{* *}$ & 23.47 & -2.12 & $37.75^{* *}$ & -12.34 \\
\hline & $(1.71)$ & $(3.33)$ & $(1.79)$ & $(0.20)$ & (3.09) & $(1.74)$ \\
\hline $\mathrm{N}=$ & 135 & 109 & 133 & 124 & 103 & 140 \\
\hline Pseudo $\mathrm{R}^{2}$ & 0.79 & 0.54 & 0.52 & 0.52 & 0.40 & 0.85 \\
\hline Loglikelihood $\mathrm{L}_{\mathrm{A}}$ & -60.0 & -123.7 & -140.5 & -135.7 & -140.5 & -43.7 \\
\hline Loglikelihood $\mathrm{L}_{0}$ & -284.6 & -267.6 & -292.8 & -280.6 & -233.7 & -291.0 \\
\hline
\end{tabular}

* Significance at 5\% level, ** significance at $1 \%$ level. Absolute t-statistics are in brackets below the coefficients. In using Generalized Least Squares panel specific AR(1) processes were added to correct for autocorrelation, and estimates are also corrected for heteroskedasticity. To gauge the goodness of fit we present two $\log$ likelihood values: $\mathrm{L}_{\mathrm{A}}$ for the full model and $\mathrm{L}_{0}$ for the model without any explanatory variables or correction for serial correlation or heteroskedasticity. 
Noteworthy is that Catholic countries are less willing to share the burden of the ICPD agenda, although this conclusion does not apply to every point on the agenda. Family planning and support of multilateral organizations are clearly not favored by governments of countries where Catholics are a dominant religious group.

The issue is somewhat different for the influence that the average income in a country (approximated by GDP per capita) exerts on the sharing of burdens. One would expect that as the average citizens in a country becomes richer that the sharing of the burden will increase. However, Addison et al. (2004) point out that the leve 1 of per capita income can also affect a donor's desire and the demand for a public good or, in the case of Addison et al., the services of a particular multilateral agency. The latter effect can possibly work in the opposite direction of the ability-to-pay effect. It remains, however, an empirical question which effect dominates. On an aggregate scale (column 6, Table 5), the income (per capita) elasticity is almost one, suggesting that one percent increase in income generates a 1 percent increase in the sharing of the burden. But as one can see from Table 5, this positive effect relates primarily to the manner in which unearmarked funds react to per capita income changes. Multilateral organizations and NGOs benefit clearly from a rise in average income in donor countries: a one percent increase in income per capita generates 1.3 percent increase in the burden share. A negative income effect is, however, clearly present in the case of basic research and this brings down the average elasticity in the aggregate.

\section{Conclusions and Discussion}

What drives the funding behavior of donor countries in light of the International Conference on Population and Development? Is it altruism or is it enlightened self-interest? Although these questions may seem moot to the policy advocates these questions go right to the heart of the entire enterprise of the ICPD. Understanding why differences in funding occur between donor countries may be the key to making the Cairo agenda a successful example of global collective action or at least understand why the financial ambitions of 1994 are out of reach (cf. Potts et al, 1999). In this study we present a first glance of the experience of population assistance developments over the years 1996-2002. Based on a dynamic panel data study of 21 donor countries we favor the interpretation that donor countries are led by enlightened self interest and do not act in accordance with the truly altruistic principles. Stated somewhat differently, donor countries are willing to contribute to the ICPD agenda, but those contributions depend on the national ability to pay and national interests and preferences and to a far lesser extent the development state of less developed countries. The lack of attention 
to conditions of the recipient is not a unique characteristic of population assistance programs, it is central to most issues of development assistance and that of global health problems in particular. This simple insight helps to explain why funds fall short of the high ambitions of ICPD. In 1994 the unmet needs of developing countries were taken as a point of departure, whereas the data reveal that donor countries take their own ability to pay as a point of departure. Furthermore, in making donations the donor countries seem to concentrate on their comparative advantages in delivering aid. Large countries concentrate on providing earmarked (bilateral) funds which deal with family planning, reproductive health, HIV/AIDS and basic research. Smaller countries prefer to provide aid through unearmarked funds, which primarily flow to multilateral agencies like UNFPA and UNAIDS and international nongovernmental organizations like IPPF. Although it is tempting to view these developments as corroboration of the 'exploitation hypothesis' and 'reverse exploitation hypothesis', respectively we do not want to claim that exploitation of the large by the small countries or the reverse situation is widespread. The specialization in giving aid or differences in preferences strikes us as a more logical explanation. In case of population aid, a mixture of motives is bound to affect donations since funding can provide private benefits which do not flow to all donors. Under such circumstances, the so-called exploitation hypothesis is not applicable (cf. Sandler and Hartley, 2001). For instance, a developed country whose border is close to a developing country with a high HIV/AIDS prevalence rate will be more inclined to donate money to their unfortunate neighboring country because with migration the disease will spread faster or because geographic proximity plays a role in the strength of empathy. The empirics of foreign aid show how important network ties (e.g., colonial ties, foreign trade) are for direction and size of aid (Schraeder, Taylor and Hook, 1998; Alesina and Dollar, 2001, Neumayer, 2003). It would be very surprising to see that population aid would not be susceptible to such self-interested motives.

Our analysis is certainly not the final verdict on motives and mechanisms driving donor funding. Given the fact that we test hypothesis at a rather aggregated level with macroeconomic data this type of analysis should be the starting point for discovering, e.g., why large countries favor bilateral channels. Furthermore, a more refined analysis should pay close attention to how reproductive health care differs from health care in general. ${ }^{9}$ 


\section{Appendix: Population Activities Covered by the Programme of Action of ICPD}

For a full description of the Programme of Action (UN-ICPD, 1995), see:

http://www.unfpa.org/icpd/icpd_poa.htm. The so-called 'costed population package' covers according the Programme of Action:

"Basic reproductive health, including family - planning services, involving support for necessary training, supplies, infrastructure and management systems, especially at the primary health-care level, would include the following major components, which should be integrated into basic national programmes for population and reproductive health:

- In the family-planning services component - contraceptive commodities and service delivery; capacity-building for information, education and communication regarding family planning and population and development issues; national capacity-building through support for training; infrastructure development and upgrading of facilities; policy development and programme evaluation; management information systems; basic service statistics; and focused efforts to ensure good quality care;

- In the basic reproductive health services component - information and routine services for prenatal, normal and safe delivery and post-natal care; abortion (as specified in paragraph 8.25, PoA); information, education and communication about reproductive health, including sexually transmitted diseases, human sexuality and responsible parenthood, and against harmful practices; adequate counselling; diagnosis and treatment for sexually transmitted diseases and other reproductive tract infections, as feasible; prevention of infertility and appropriate treatment, where feasible; and referrals, education and counselling services for sexually transmitted diseases, including HIV/AIDS, and for pregnancy and delivery complications;

- In the sexually transmitted diseases/HIV/AIDS prevention programme component mass media and in-school education programmes, promotion of voluntary abstinence and responsible sexual behaviour and expanded distribution of condoms;

- In the basic research, data and population and development policy analysis component - national capacity-building through support for demographic as well as programme-related data collection and analysis, research, policy development and training." 


\section{References}

Addison, T., M. McGillivray, and M. Odedokun, 2004, Donor Funding of Multilateral Aid Agencies: Determining Factors and Revealed Burden Sharing, World Economy, 173191.

Alesina, A., and D. Dollar, 2000, Who Gives Foreign Aid to Whom and Why?, Journal of Economic Growth, 5: 33-63.

Barro, R.J., and R.M. McCleary, 2004, Which Countries Have State Religions?, NBER Working Paper, no. 10438, Cambridge MA.

Bulatao, R.A., 1998, The Value of Family Planning Programs in Developing Countries, RAND corporation, St. Monica.

Dixit, A.K., 1996, The Making of Economic Policy: A Transaction-Cost Politics Perspective, MIT Press, Cambridge, MA.

Eurobarometer, 2005, Attitudes Towards Development Aid, Special Eurobarometer 222/ wave 62.2, Brussels.

Iannaccone, L., 1998, Introduction to the Economics of Religion, Journal of Economic Literature, 36: 1465-1496.

Jha, P., et al. 2002, Improving the Health of the Global Poor, Science, 295: 2036-2039.

Knack, S. en A. Rahman, 2004, Donor Fragmentation and Bureaucratic Quality in Aid Recipients, World Bank Policy Research Working Paper 3186, Washington DC.

Kremer, M., 2002, Pharmaceuticals and the Developing World, Journal of Economic Perspectives, 16: 67-90.

Neumayer, E., 2003, Do Human Rights Matter in Bilateral Aid Allocation? A Quantitative Analysis of 21 Donor Countries, Social Science Quarterly, 84: 650-666.

Olson, M., and R. Zeckhauser, 1966, An Economic Theory of Alliances, Review of Economics and Statistics, 48: 266-279.

Potts, M., J. Walsh, J. McAninch, N. Mizoguchi, and T.J. Wade, 1999, Paying for Reproductive Health Care: What is Needed, and What is Available?, International Family Planning Perspectives, 25: S10-S16.

Regnerus, M.D., C. Smith and D. Sikkink, 1998, Who Gives to the Poor? The Influence of Religious Tradition and Political Location on the Personal Generosity of Americans Toward to Poor, Journal for the Scientific Study of Religion, 37: 481-494.

Sandler, T., 2004, Global Collective Action, Cambridge University Press, Cambridge. 
Sandler, T., and D.G. Arce M., 2002, A Conceptual Framework for Understanding Global and Transnational Public Goods for Health, Fiscal Studies, 23: 195-222.

Sandler, T., and K. Hartley, 2001, Economics of Alliances: The Lessons of Collective Action, Journal of Economic Literature, 39: 869-896.

Sandler, T., and J.C. Murdoch, 2000, On Sharing NATO Defence Burdens in the 1990s and Beyond, Fiscal Studies, 21: 297-327.

Schindlmayer, T., 2001, The Media, Public Opinion and Population Assistance: Establishing the Link, International Family Planning Perspectives, 27: 42-46.

Schindlmayr, T., 2004, Explicating Donor Trends for Population Assistance, Population Research and Policy Review, 23: 25-54.

Schraeder, P.J., B. Taylor, and S.W. Hook, 1998, Clarifying the Foreign Aid Puzzle: A Comparison of American, Japanese, French and Swedish Aid, World Politics, 50: 294 323.

UNESCO, 2000, World Culture Report-Cultural Diversity, Conflict and Pluralism, UNESCO, Paris.

UNFPA, 2003, Financial Resource Flows for Population Activities in 2001, UN, New York.

Van Dalen, H.P. and M. Reuser, 2005, Assessing Size and Structure of World Wide Funds for Population and AIDS Activities, NIDI report, see: www.resourceflows.org, The Hague.

World Health Organization (WHO), 2002, Coordinates 2002: Charting Progress against AIDS, TB and Malaria, Geneva: WHO. 


\section{ENDNOTES}

${ }^{1}$ This clause w as made explicit for donor countries in the Programme of Action (par. 14.11), and it was once explicated for developing countries in one of the preparatory committees, see:

http://www.un.org/popin/icpd/newslett/94_13/2prepcom.html

${ }^{2}$ Previously published under the title Global Population Assistance Report published annually by UNFPA.

${ }^{3}$ In the statistical analysis we will exclude the new or emerging donor countries: Greece, Republic of Korea, Turkey and the new members of the European Union (like the Czech Republic, Slovakia, Poland and Estonia) because of lack of substantial data and we exclude the European Union as a separate entity because we can not put it on the same footing as the behavior of individual donor countries.

${ }^{4}$ For instance, the influential demography journal International Family Planning Perspectives receives funding from the U.S. Agency for International Development, and it is therefore prohibited under the Helms Amendment (P.L. 93 -189) from publishing material that promotes abortion.

${ }^{5}$ At present it is too early to examine the consequences of the Mexico City Policy and we will refrain from doing so.

${ }^{6}$ The estimation model used is Generalized Least Squares with panel specific autoregressive processes of order $1, \operatorname{AR}(1)$ to correct for serial correlation in errors, and a correction for heteroskedasticity, i.e. differences in variance across panel members.

${ }^{7}$ We have considered alternative religious variables such as the leading religion in a country, the level of religious pluralism or the fact that a country has a state religion (see Barro and McCleary, 2004). The two most dominant religions of a country provided the best fit, although the conclusions do not differ substantially when alternative religious variables are used. The two most dominant religions in a country have been used as our preferred choice of religion variable.

${ }^{8}$ Spearman's $\rho$ statistic is calculated in the same manner as the Pearson correlation coefficient exc ept that the ranks of the data replace the actual measurements, making the statistic robust to outliers and minor measurement errors that do not alter the rankings.

${ }^{9}$ A typical problem in the case of global health care is that the health problems of the developed world differ quite distinctly from those of the developing world. Priorities in investing in new medicines, vaccines and treatments are bound to be affected by this divergence of interests. It is what is typically called the '90/10 gap' by the WHO (2002: 23): less that 10 percent of the US annual spending on healthrelated research and development, addresses the health concerns of 90 percent of the global population. Citizens of the developed world primarily suffer from non-communicable diseases, whereas citizens in LDCs suffer from infectious and parasitic diseases (Kremer, 2002). It goes without saying that infectious diseases like HIV/AIDS or Sexually Transmitted Diseases (STDs) call for a different approach than non-infectious diseases (Sandler and Arce, 2002). 